\title{
Implementation of Pancasila Values in Scouting Activities (Case study at SMP Negeri 1 Mallusetasi Barru Regency)
}

\author{
Rismawati \\ Civic Education Study Program Universitas Muhammadiyah Makassar Indonesia \\ rismawati@unismuh.ac.id
}

\begin{abstract}
This study aims to determine how the implementation of Pancasila values in Scouting activities and what are the inhibiting factors and supporting factors for the Implementation of Pancasila values in Scouting activities. The benefits of this study use the theoretical benefits and practical benefits. This type of research is descriptive with a qualitative approach. Data collection techniques and data analysis techniques using interviews, and documentation. The results of this study indicate that: (1) The application of the divine value is evident from the observance of the members of the Boy Scouts in practising the teachings of Religion. The application of human values can be seen from the love between Scout members. Application of the value of unity seems to be carried out activities always prioritize to foster a sense of togetherness. The application of popular values can be seen from the preservation of democracy in scouting activities. Fairness values can be seen from the tolerance level of Scout members, as well as the Scoutmaster who is being fair. (2) Inhibiting factors lack of selfawareness to obey the rules, lack of cooperation in the task, the number of negative behaviours from outside. And Supporting Factors become more independent individuals, raise awareness, train discipline, learn Scout organizations well and train leadership, improve themselves to always apply the values of Pancasila such as diligently worshipping so that hearts and minds become calm.
\end{abstract}

Keywords: Pancasila, the implementation of the values of Pancasila, Scouting

\begin{abstract}
Abstrak. Penelitian ini bertujuan untuk mengetahui bagaimanakah Implementasi nilai-nilai pancasila dalam kegiatan Kepramukaan dan apa faktor penghambat dan faktor pendukung Implementasi nilainilai pancasila dalam kegiatan Kepramukaan. Manfaat penelitian ini menggunakan manfaat teoritis dan manfaat praktis. Jenis penelitian yang digunakan adalah deskriptif dengan pendekatan kualitatif. Teknik pengumpulan data dan teknik analisis data menggunakan wawancara, dan dokumentasi. Hasil penelitian ini menunjukkan bahwa: (1) Penerapan nilai ketuhanan tampak terlihat dari ketaatanan aggota pramuka dalam mengamalkan ajaran-ajaran Agama. Penerapan nilai kemanusiaan tampak dari rasa kasih sayang antar anggota Pramuka. Penerapan nilai persatuan tampak kegiatan yang dilakukan selalu mengedepankan untuk memupuk rasa kebersamaan. Penerapan nilai kerakyatan tampak dari terjaganya demokrasi dalam kegiatan kepramukaan. Nilai Keadilan tampak dari tingkat toleransi anggota Pramuka, serta Pembina Pramuka yang bersikap adil. (2) Faktor Penghambat kurangnya kesadaran pada diri sendiri untuk patuh pada peraturan, kurangnya kerjasama dalam tugas, banyaknya perilaku negatif dari luar. Dan Faktor Pendukung menjadi pribadi yang lebih mandiri, meningkatkan kepedulian, melatih kedisiplinan, belajar organisasi Pramuka dengan baik dan melatih kepemimpinan, lebih membenahi diri untuk selalu menerapkan nilai-nilai Pancasila seperti rajin beribadah agar hati dan pikiran menjadi tenang.
\end{abstract}

Kata Kunci: Pancasila, implementasi nilai-nilai Pancasila, Kepramukaan. 


\section{INTRODUCTION}

Pancasila is an ideology of the Indonesian people that was born from the culture and history of Indonesian society that existed long before the Indonesian people became independent. Pancasila as an ideology of the Indonesian people has a noble value which is reflected in the principles of Pancasila. The Godhead contained in the first principle of Pancasila shows that the Indonesian people placed God in the highest position and this is not a value that suddenly appears. (Susanti 2013: 1).

Constitution of The Republic of Indonesia No. 20 of 2003 concerning the National Education System it is implied that Education is organized as a process of civilizing and empowering students that lasts throughout life. In general, what is meant by culture is the process of developing values, norms and morals in individuals through the process of involving students in the Education process which is an integral part of the Indonesian nation's cultural process. To realize the goals of National Education requires strategy and effort as well as support from all aspects both materially and physically. The implementation of Pancasila values has increasingly declined. The decline in the implementation of Pancasila values is increasingly felt when the MPR Decree No. TAP no longer applies. II / MPR / 1978 with the issuance of TAP MPR No. XVIII / MPR / 1998. TAP MPR No. II / MPR / 1978 contains guidelines on how to practice (Pancasila values are more commonly known as $\mathrm{P} 4$ (Guidelines, Appreciation and Practicing, Pancasila). There is a link between Scouting activities with Pancasila, namely in Scouting known as Dhasa Darma Pramuka. Dhasa Darma Pramuka is an embodiment of the values contained in Pancasila, where scouting education is considered one of the important aspects of national education and part of the struggle of the Indonesian nation. building society and nation with personality in accordance with the philosophy and purpose of life of the Indonesian nation, Pancasila.

The Scout Movement as part of national education has the aim of forming each scout to have a personality that is faithful, devoted, noble, patriotic, law-abiding, disciplined, upholds the nation's noble values, and has the life skills as a cadre of the nation in protecting and developing the Unitary State of Republic of Indonesia practices the Pancasila and preserves the environment. Implementation of the values of Pancasila is an obligation for the people of Indonesia, especially Scout members. Pancasila values are reflected in the Statutes and Bylaws of the Scout Movement.

However, obstacles encountered in the development of scouting education began to be less desirable. Because many students do not know the meaning of Scouting itself. Through scouting education, students are trained to grow and implement Pancasila values (the 
values of God, humanity, unity, society and justice). Such as performing ceremonies carried out before and after starting Scout training, Marching, LBB, adventure (nature exploring), camping, games, rigging and so on.

In addition, in its implementation, another obstacle faced in the development of scouting education was that it began to be less desirable because students still considered Scouting activities only as a facility for extracurricular activities at school. Besides involvement or influential people in the course of Scouting activities is a factor in the running of Scouting activities. The most important thing is that the facilities and infrastructure for Scouting activities at school are still inadequate. In addition, the assumption that Scouting activities still carry out ancient activities, along with the development of scouting times, still uses traditional and simple tools.

On the other hand, many students themselves are less interested in Scouting activities, due to the orientation of student learning focused on the orientation of values in general subjects, especially the tested subjects. So the orientation of students considers Scout activities as additional activities that are less important. According to Hidayah (2010: 4) this is due to students not yet understanding the values behind the simplicity and traditional ways that are still maintained in Scouting activities held until now. Yet behind the simplicity of Scouting, if understood seriously can lead students to develop the potential of students.

\section{RESEARCH METHODS}

This type of research used qualitative with descriptive methods. Creswell (2010,) argues that "Qualitative Research is methods for understanding the meaning collected by individuals or groups that were ascribed to social problems and blessings". Qualitative research relied on a natural background holistically, positioning humans as research tools, conducting data analysis inductively, prioritizing the process of the results of research conducted by researchers and researchers. Descriptive method was chosen because the research conducted to current events and concerning present conditions. So in this study, the data did not consist of numbers consisting of words that were either written orally. This research was conducted at SMP Negeri 1 Mallusetasi located on Jl.Poros Makassar-Parepare, Palanro Village, Mallusetasi District Barru Regency. The subject of this research was Mallusetasi 1 Public Middle School. This research was approved by the scout members. There were 6 students, with 3 male students and 3 female students. Data collection techniques used in this study were interviews to obtain data or information by asking questions directly to the informant, namely the Scouting core management at SMP Negeri 1 Mallusetasi 
Barru Regency about various matters relating to the development of Pancasila values in Scouting curricular activities. The documentation here was an amalgamation of data consisting of data and data stored in the form of documents which were the Front Cluster Activity Program 10,089-10,090 and the Cluster Annual Work Program 10,08910,090 in SMP Negeri 1 Mallusetasi Barru Regency.

\section{DISCUSSION}

Scouting education in accordance with Constitution of the Republic of Indonesia number 12 of 2010 Article 4 which aims to form every student to have faithfulness, piety, noble character, patriotic spirit, obedient law, discipline, upholding the nation's noble values and having skills live as a cadre of the nation in protecting and developing the Unitary State of Republic of Indonesia, practising Pancasila, and preserving the environment.

The Republic of Indonesia, practice Pancasila and preserve the environment. Scouting education as one of the compulsory extracurricular activities in schools can be a place for the formation of the soul of nationalism and nationalism of children from an early age. Through the Scouting movement, the soul and spirit of mutual cooperation and awareness will be embedded in the diversity that exists in Indonesia. Scouting education is very relevant to the formation of nationalism in children, this is evidenced by the similarity of the values of national character values with the values of Dasa Dharma in Scouting, so it is very appropriate that through Scouting the education of national character values is instilled.

The relevance of Scouting activities at SMP Negeri 1 Mallusetasi is very supportive in instilling the values of national character. This can be seen through a variety of Scout activities, namely: opening and closing ceremonies during routine training activities, testing the Special Skills Requirements (SKU), camping activities, and Social Service. These activities are designed according to the needs of students (Scout members) and adjusted to the scouting function which is activities that are interesting for children and youth, devotion (jobs) for adults, and tools (means) for the community and organization.

The Development of Pancasila Values integrated through Scouting Activities in SMP Negeri 1 Mallusetasi has instilled national character values in children from an early age, children already have a brave character, are independent and are responsible for their duties and responsibilities. Therefore, it is expected that children will be more ready to face all multi-dimensional obstacles in the future. Scouting as one of the extracurricular activities in schools is very relevant to the development of Pancasila values, what is meant is the nation's character values as evidenced by the similarity of values in the education of nation's character values with the 
values of Dasa Dharma, so it is very appropriate when scouting through character education nation implanted. Every scouting activity involves planting a love of nature and the environment, besides continuing to educate children to be disciplined in various fields of life. Solidarity among people is also one of the fields created by the Scout Movement. With the education of the nation's character values carried out in scouting activities, little by little the attitudes and behaviour of children (Scout members) begin to progress progressively. For example, children begin to recognize the national history of the Republic of Indonesia, able to memorize struggle songs, be brave in every activity, and act immediately when there are friends who need help. Thus, children can later display the values of the character of the Indonesian people through their daily lives.

Scouting activities held at SMP Negeri 1 Mallusetasi, namely: Routine training activities carried out every Friday, Persami, Pionering, Semaphore, LKBB, Tali Temali Practicing Pancasila, Public Speaking and Social Service. All of these activities are work programs of Mallusetasi 1 State Junior High School Base. Values are instilled through scouting activities at Mallusetasi 1 State Junior High School. Includes national values, respect for achievement, love for the motherland, creativity, care for the environment, courage, independence and responsibility.

Based on the results of research at SMP Negeri 1 Mallusetasi, it can be seen that the development of Pancasila values, especially the national character values in Scout extracurricular activities, is related to national and state awareness, love of the motherland, belief in Pancasila, willingness to sacrifice for the nation and state and the ability to start defending country.

In implementing Indonesian national and state awareness material in the Scouting activities, the coach requires children to speak in the Indonesian language properly and correctly. The assignment of groups to make flagpoles and then enforce the red and white flag is also an effort to instil an attitude of national and state awareness

Cultivating the attitude of patriotism through scouting activities at SMP Negeri 1 Mallusetasi is carried out by the coach by inviting the Scouts to sing the national anthem of Indonesia Raya before giving Scout material, each routine training activity also carries out a ceremony in which there is respect for the red and white flag, introducing children in the results of Indonesia's natural wealth in the form of spices, and the cultivation of love for the motherland are also done through games that can build a spirit of love for the motherland and contain the values of children's cooperation. In each of the Scout activities, the coach always introduces children to the various cultures of the State of Indonesia.

Cultivating the attitude of patriotism through scouting activities at SMP Negeri 1 
Mallusetasi is carried out by the coach to invite the Scouts to sing the national anthem of Indonesia Raya before giving Scout material, each routine training activity also carries out a ceremony in which there is respect for the red and white flag, introducing children in the results of Indonesia's natural wealth in the form of spices, and the cultivation of love for the motherland is also done through games that can build a spirit of love for the motherland and contain the values of children's cooperation. In each of the Scout activities, the coach always introduces children to the various cultures of the State of Indonesia.

Scouting education also plays a role in shaping children to have the initial ability to defend the country. The ability to defend the country psychologically and mentally is done by instilling children to have a brave attitude. The method used by the coach is to offer children who want to be officers to recite the Dasa Dharma, to do night shift activities at camp, to instil a disciplined attitude by asking children to arrive on time, wearing a full Scout uniform and all its attributes. It also develops an attitude of responsibility through assigning individuals or groups.

In Scouting Education which is closely related to the values of the nation's character, children are directly involved in planting and developing these values and practising them in daily life. Children learn by the way he lives. In scouting education, many activities encourage children to become brave and confident individuals. Scout activities are packaged in an interesting and fun form of educational games that do not neglect the values of the nation's character in its implementation

In scouting it is not the material or content of the lesson that is more important but it breeds and fosters good attitudes and actions that will shape the intelligence, physical strength and character of the self. This can be seen in the way the team and group work where they are invited to work together as a team in achieving a common goal so that the group can be seen practising in democracy, even that is Pancasila democracy in practice. Scouts are training and education platforms that produce or print generations who can coexist with their surroundings and under any circumstances that cannot only depend on others.

Efforts to instil character values there are several factors that can influence the success or failure of a process of planting the values of Pancasila, especially the Nation Character Value. Differences in the attitudes or behaviour of each human being are different, this can be influenced by influences originating from oneself and motivation originating from outside himself.

The value of responsibility through scouting extracurricular activities at SMP Negeri 1 Mallusetasi has several supporting and inhibiting factors.

Supporting factors in the implementation of Pancasila value education 
in scouting activities at SMP Negeri 1 Mallusetasi. Includes supporting infrastructure, the inclusion of Scouting Education as a compulsory extracurricular, the quality of the coach and the support of the family.

While the inhibitors in the implementation of Pancasila value education through scouting activities in SMP Negeri 1 Mallusetasi. Consists of internal and external obstacles. Barriers arising from internal factors include feeling tired of children because of many tasks from school, the limited funding of activities to develop the implementation of national value education through scouting activities. While barriers from external factors are differences in the character of the environment between the school environment with the surrounding community.

\section{CONCLUSION}

Based on the results of research on the implementation of the values of Pancasila in SMP Negeri 1 Mallusetasi went well. The application of the divine value can be seen from the obedience of scout members in practising the teachings of Religion. The application of human values can be seen from the love between the Scouts. Application of the value of unity seems to be carried out activities always prioritize to foster a sense of togetherness. The application of popular values can be seen from the preservation of democracy in scouting activities. This can be seen from the freedom of Scout members to hold deliberations in deciding problems. The value of Justice can be seen from the tolerance level of Scout members, as well as the Scoutmaster who is fair without discriminating among Scout members.

Factors that support the activities in the development of Pancasila values are supporting infrastructure, the inclusion of scouting education as a compulsory extracurricular, quality of mentoring and support from families. The existing barriers are divided into two namely internal and external barriers. Internal barriers include the fatigue of children due to the many tasks from school, the limited funding for activities to develop the nation's character values through scouting activities. External barriers are differences in the character of the environment between the school environment and the surrounding community. Scouting activities should be increased in the implementation of activities in schools because scouting activities are very useful in developing and fostering students' mentality in preparing for a brighter future and must be supported by all parties so that the activities that have been programmed by students can be well implemented. Schools as educational institutions are reasonable to support and care for various activities that exist and for Scout Members to create short-term and long-term work programs and for Scout Guides to carry out coaching have a syllabus 
so that activities can be directed following the objectives to be achieved

\section{REFERENCES}

[1] Anggaran Dasar Gerakan Pramuka

[2] Arikunto.Suharsimi. (2010). Prosedur Penelitian Suatu Pendekatan Praktik.Jakarta: Rineka Cipta

[3] Christanto, Yan Adi Dan Sarmini. (2015). Konstruksi Masyarakat Samin Tentang NilaiNilai Pancasila Di Dusun Jepang Kecamatan Margomulyo Bojonegoro Kajian Moral dan Kewarganegaraan. Volume 01 Nomor03 Tahun 2015, Hal 54-70

[4] Creswell. (2010). Metode Penelitian Kualitatif: Sebuah Upaya mendukung Penggunaan Penelitian Kualitatif dalam Berbagai Disiplin Ilmu.Jakarta: Raja Grafindo Persada.

[5] Herdiansyah, Haris. (2013). Wawancara, Observasi, dan Focus Groups: Sebagai Data Kualitatif. Jakarta: Rajawali Pers

[6] Heri Gunawan, (2012). Pendidikan Karakter Konsep dan Implementasi. Bandung: Alfabeta.

[7] J. Tjiptabudy, (2010). Kebijakan Pemerintah Dalam Upaya Melestarikan Nilai-Nilai Pancasila Di Era Reformasi Jurnal Sasi Vol.16. No.3 Juli September 2010

[8] Kasmawati Andi. (2011). Dasar dan Konsep Pendidikan Moral. Makassar: PPKn Fakultas Ilmu Sosial Universitas Negeri Makassar.

[9] Kemendiknas. (2010). Pengembangan Pendidikan Budaya Sebagai Karakter Bangsa. Jakarta: Kemendiknas.

[10] Kurnisar. (2012). Pancasila Sumber Dari Segala Sumber Hukum Di Indonesia Universitas Sriwijaya Palembang 2012 ISSN $1412 \quad$ - $8683 \quad$ 243didownload ejournal.undiksha.ac.id/index.php/Mkfis/arti cle/download/467/385

[11] Kwarnas. (2013). Gerakan Pramuka, Anggaran Dasar dan Anggaran Rumah Tangga.Jakarta : Kwarnas.
[12] Lampiran Peraturan Menteri Pendidikan Nasional Nomor 23 Tahun 2006 Tentang Standar Kompetensi Lulusan Untuk Satuan Pendidikan Dasar Dan Menengah

[13] Lukman Santoso Az, (2014) Panduan Terlengkap Pramuka (Jogjakarta: Buku Biru,

[14] Maftuh, Bunyamin. (2008). Internalisasi Nilai-Nilai Pancasila dan Nasionalisme Melalui Pendidikan Kewarganegaraan. Jurnal Educationist Vol. II

[15] Mardalis. (2010). Metode Penelitian: suatu pendekatan proposal. Jakarta: Bumi Aksara

[16] Mas'ut, (2014). Pengaruh Kegiatan Ekstra Kurikuler Pramuka

[17] Ms, Bakry Noor. (2010). Pendidikan Pancasila. Yogyakarta: Pustaka Pelajar

[18] Mulyasa. (2011). Berbasis Kompetensi Konsep, Karakteristik, dan Implementasi.Bandung: .PT Remaja Rosdakarya

[19] Pancasila Dan Bhineka Tunggal Ika Solusi Heterogenitas. Jurnal Transnasional, Vol. 4, No. 2,

[20] Peraturan Menteri Pendidikan dan Kebudayaan RInomor 81A tahun 2013 tentang Implementasi Kurikulum 2013.

[21] Sugiyono. (2010). Metode Penelitian Pendidikan Pendekatan Kuantitatif, Kualitatif, dan $R \& D$. Bandung: Alfabeta. Tjarsono, Idjang. 2013. Demokrasi

[22] Syarbani, Syahrial, dkk. (2006). Membangun Karakter dan Kepribadian melalui Pendidikan Kewarganegaraan. Yogyakarta: Graha Ilmu.

[23] Undang-Undang nomor 12 tahun 2010 tentang Gerakan Pramuka.

[24] Undang-Undang Republik Indonesia Nomor 20 Tahun 2003 Tentang Sistem Pendidikan Nasional

[25] Warsito. (2012). Pendidikan Pancasila Era Reformasi. Yogyakarta: Ombak 
[26] Widjaja. (2010). Penerapan Nilai-nilai Pancasila dan HAM di Indonesia. Jakarta: Rineka Cipta

[27] Widodo, HS, Agus, (2011). Ramuan Lengkap Bagi Pramuka Penggalang Pramuka Penegak dan Pembina.Yogyakarta: Kwartir Daerah XII DIY 